\title{
Roles of TGF $\beta$ signaling Smads in squamous cell carcinoma
}

\author{
Gangwen Han and Xiao-Jing Wang ${ }^{*}$
}

\begin{abstract}
Smad proteins are classified in different groups based on their functions in mediating transforming growth factor $\beta$ (TGF $\beta$ ) superfamily components. Smad1/5/8 mainly mediate bone morphogenetic proteins (BMP) pathway and Smad2/3 mainly mediate TGF $\beta$ pathway. Smad4 functions as common Smad to mediate both pathways. Previous studies showed many members of TGF $\beta$ superfamily play a role in carcinogenesis. The current review focuses on the role of TGF $\beta$ signaling Smads in squamous cell carcinomas (SCCs). TGF $\beta$ signaling inhibits early tumor development, but promotes tumor progression in the late stage. Although Smad2, Smad3 and Smad4 are all TGF $\beta$ signaling Smads, they play different roles in SCCs. Genetically, Smad2 and Smad4 are frequently mutated or deleted in certain human cancers whereas Smad3 mutation or deletion is infrequent. Genetically engineered mouse models with these individual Smad deletions have provided important tools to identify their diversified roles in cancer. Using these models, we have shown that Smad4 functions as a potent tumor suppressor and its loss causes spontaneous SCCS development; Smad2 functions as a tumor suppressor and its loss promotes SCC formation initiated by other genetic insults but is insufficient to initiate tumor formation. In contrast, Smad3 primarily mediates TGF $\beta$-induced inflammation. The functions of each Smad also depends on the presence/ absence of its Smad partner, thus need to be interpreted in a context-specific manner.
\end{abstract}

Keywords: Smad2, Smad3, Smad4, squamous cell carcinomas, TGF $\beta$ signaling

\section{TGF $\beta /$ Smad signaling}

The transforming growth factor $\beta$ (TGF $\beta$ ) signaling pathway has been implicated in the regulation of various biological processes including embryonic development, fibrosis, tumor development, immunity regulation and wound healing. Function of the TGF $\beta$ signaling pathway depends on the binding of ligands to cell membrane receptors, activating cytoplasm mediators into the nucleus, and regulating expression of their target gene. The ligands of the immediate TGF $\beta$ family include 3 isoforms (TGF $\beta 1,2,3)$. Cell-surface receptors of TGF $\beta$ signaling are mainly classified into two subtypes: type I (TGF $\beta$ RI) and type II (TGF $\beta$ RII). Smad-dependent TGF $\beta$ signaling from cytoplasm to nucleus are primarily three $\mathrm{Smad}$ isoforms in the Smad family, i.e., Smad2, 3, and 4. The binding of ligands to TGF $\beta$ RII leads TGF $\beta$ RI to phosphorylate Smad2 and Smad3, which then bind to Smad4 forming

\footnotetext{
* Correspondence: XJ.Wang@ucdenver.edu

Department of Pathology, University of Colorado Denver, Aurora, CO 80045,
} USA

\section{Biomed Central}

a trimeric complex and translocate into the nucleus. In the nucleus, the Smad trimeric complex binds the Smad binding element (SBE) of target genes, regulating expression of TGF $\beta$ response genes directly or through recruiting other co-factors (co-activators or co-repressors) to target genes $[1,2]$ (Figure 1).

The TGF $\beta$ signaling pathway has been reported to play either a suppressive or a promotive role in cancer development depending on tumor stage and type $[3,4]$. Evidence for the suppressive role of TGF $\beta$ signaling in cancer includes genomic deletion/mutation with several core components of TGF $\beta$ signaling identified in human cancers $[5,6]$ and TGF $\beta$ mediated cell growth inhibition and apoptosis. However, TGF $\beta$ induces angiogenesis, inflammation and epithelial-mesenchymal transition (EMT) providing a beneficial environment for tumor progression and metastasis. The current review will focus on recent progress elucidating the role of TGF $\beta$ signaling Smads in squamous cell carcinoma (SCC). 


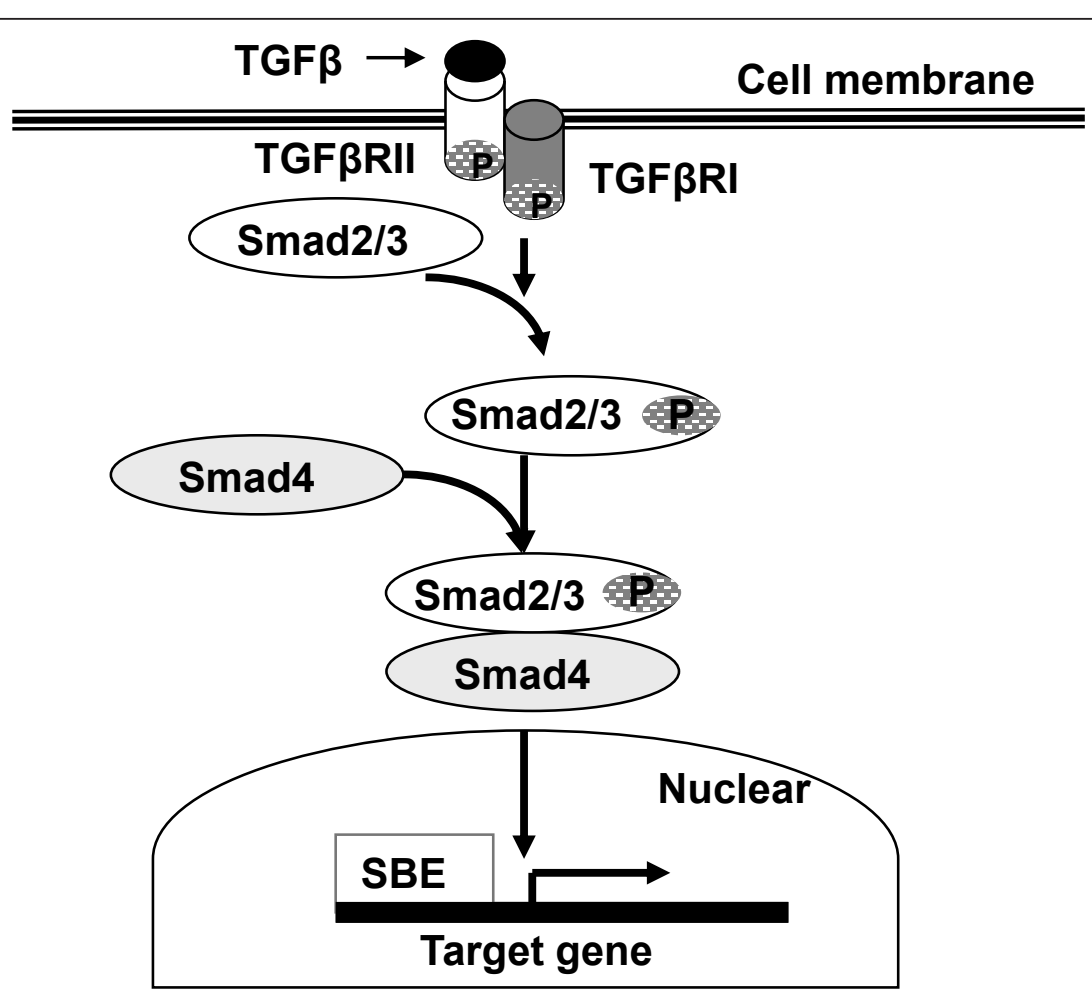

Figure 1 Schematic of Smads mediated TGF $\beta$ signaling pathway. TGF $\beta$ ligand binds to TGF $\beta$ RII/TGF $\beta$ RI receptors leading to phosphorylation of Smad2/3. Phosphorylated Smad2/3 binds to Smad4 to form a protein complex that undergoes nuclear translocation and regulates the expression of TGF $\beta$ target genes through binding to the Smad-binding element (SBE).

The role of Smad2 in SCC

\section{Aberrant Smad2 in human cancer}

Smad2 maps to the 18q21 chromosome, near the Smad4 locus in the human genome [7]. Mutation analysis identified 6\% colon cancers with missense mutations in $\mathrm{MH} 2$ or MH1 of Smad2. Biochemical and functional analysis indicated these mutations were loss of functional mutations [7]. Subsequent studies have shown mutations of Smad2 in lung cancer and hepatocellular carcinoma [8,9]. In SCC, Smad2 point mutation is infrequent in human head and neck SCC (HNSCC) [10-12] with only one report of a Smad2 mutant HNSCC cell line [13]. However, we have found about $67 \%$ of poorly differentiated human skin SCCs have loss of heterozygosity (LOH) at the Smad2 locus [14]. By immunostaining, 70\% human skin SCC show Smad2 protein reduction/loss in tumor tissues, especially, the incidence of Smad2 loss is higher in poorly differentiated SCCs [14]. In addition, loss or reduction of Smad2 expression has been shown in other human SCCs including genital SCC, oral SCC and cervical SCC [15-18].

Smad2 loss is not a tumor initiating event but promotes skin carcinogenesis in vivo

Germline Smad2 deletion in mice causes embryonic lethality [19-22]; heterozygous Smad2 mice are viable, fertile, and no spontaneous tumors develope in their lifespan. Specific targeted Smad2 disruption to hepatocytes does not affect the liver development, however hepatocyte-specific Smad2 deletion increases CCL4induced hepatocyte proliferation and spontaneous acquired EMT in vitro [23]. In Smad2/APC (adenomatous polyposis coli) double heterozygous mice, Smad2 deletion accelerates APC mutation-induced intestinal tumor growth and invasion but does not increase the number of tumors [24]. Smad2 heterozygous mice (Smad2+/-) do not develop spontaneous cancer in any tissues. However, when Smad2+/- mice were exposed to a two-stage chemical carcinogenesis protocol, they developed a greater number of less-differentiated tumors with locally invasive and EMT in comparison with wild type control mice [25]. To fully understand the in vivo role of Smad2 in skin carcinogenesis, we have established Smad2 conditional knockout mice that targeted Smad2 deletion to epithelial cells using the keratin 5 (K5) promoter, in which keratinocyte-specific Smad2 deletion in homozygous (K5.Smad2-/-) or heterozygous (K5.Smad2+/-) mice can be induced by RU486 [14]. K5. Smad2-/- mice do not develop spontaneous skin tumors, but have accelerated tumor formation and malignant conversion in a two-stage chemical carcinogenesis 
experiment. K5.Smad2-/- tumors are more poorly differentiated, exhibited increased EMT and angiogenesis. These results indicate Smad2 deletion in the skin is not a tumor initiating event, but Smad2-deficient epidermis is more susceptible to skin tumor formation and malignant conversion.

\section{Smad2 loss induced EMT and angiogenesis through upregulation of Snail and HGF}

TGF $\beta$ is well documented as an inducer of EMT [26] and a potent stimulator of angiogenesis [27], however, neither TGF $\beta$ nor its target VEGF, which are usually elevated in tumor cells and contribute to angiogenesis and tumor metastasis [28,29], is increased in $\mathrm{K} 5$. Smad2-/- SCC [30]. Furthermore, K5.Smad2-/- tumors do not have increased levels of Smad-independent TGF $\beta$ signaling factors related to EMT, i.e., pJNK, pERK, and pMAPK. Further analyses revealed that expression of Snail, a TGF $\beta$ target gene functioning as a transcriptional repressor of E-cadherin [31], was activated by increased Smad4 binding to SBE of the Snail promoter in K5.Smad2-/- skin [14]. At the transcriptional level, Smad3 usually directly binds to the SBE of a target gene, and subsequently recruits Smad4 to the same SBE. Smad2 does not bind to DNA directly but complexes with Smad3 and Smad4 as either a co-activator or a co-repressor for Smad3 and Smad4 [32]. Therefore, loss of Smad2 binding to Snail's SBE increases Snail expression dependent on recruitment of Smad4 to Snail's SBE through Smad3; this process contributes to EMT. Similarly, Smad3 and Smad4 over Smad2 in mediating EMT have also been observed in other cell types $[23,26,33,34]$.

With respect to Smad2 loss-associated angiogenesis, we have found that K5.Smad2-/- tissue expresses higher levels of hepatocyte growth factor (HGF) that activates its receptor c-Met in endothelial cells [30]. HGF is an independent, potent angiogenic factor via stimulation of endothelial cell growth, migration, scatter, and elongation which favors formation of a microenvironment beneficial for tumor development and invasion [35,36]. In keratinocytes, Smad-2, -3 , and -4 all bind to SBE of the HGF promoter [30]. However, Smad2 recruits co-repressors including TGIF and HDAC to the SBE site, but Smad4 mainly recruits co-activators CBP/p300. Smad2 deletion in keratinocytes dramatically increased the binding of Smad4/CBP/p300 complex to the SBE site of the HGF promoter and resulted in overexpression of HGF. Consistent with our biochemical analyses, human SCCs from the skin or head and neck, Smad2-negative tumors have higher HGF expression; however, once Smad3 and Smad4 are lost, HGF expression is also abrogated [30]. Furthermore, short term of treatment with a c-Met inhibitor significantly reduced Smad2 loss- associated angiogenesis [30], showing a potential application of c-Met inhibitor in treating human SCC with Smad2 loss.

\section{The role of Smad3 in SCC}

\section{Aberrant Smad3 in human cancer}

Smad3 is located in 15q21-q22 of human chromosome. Recent publications indicate Smad3 mutations are associated with familial thoracic aortic aneurysms and dissections $[37,38]$. Smad3 mutation has been identified in one colorectal cancer cell line [39], and is infrequent in human colon cancer tissues and breast cancers [40-42]. Smad3 missense mutation was identified in HNSCC at a very low frequency, but it remains to be determined if this is a driver mutation [43]. In human cancers, the loss of Smad3 expression has been associated with various malignant carcinomas and is recognized as a tumor suppressor [44-46]. However, Smad3 protein loss is not common in skin SCC [14] and increased Smad3 expression has been reported in breast cancer [41].

\section{Tumor suppressive effects of Smad3}

In hematopoiesis, Smad3 plays a major role in TGF $\beta$ mediated growth inhibition [47]. In order to define the role of Smad3 in tumorigenesis, Smad3 deletion or overexpression has been investigated in vitro and in vivo. Smad3-/- keratinocytes derived from Smad3-/- neonates and transduced with v-ras ${ }^{\mathrm{Ha}}$ demonstrated reduction of TGF $\beta$ induced cell growth arrest and induction of keratin 8 , a marker of simple epithelia and malignant conversion of squamous cell carcinomas. When grafted onto nude mice, v-ras ${ }^{\mathrm{Ha}}$-transduced Smad3-/- keratinocytes developed papilloma and progressed to SCC, but v-ras ${ }^{\mathrm{Ha}}$-transduced Smad3+/+ keratinocytes only formed papillomas $[48,49]$. The studies suggest Smad3 does not alter proliferation, but prevents malignant conversion of papillomas formed by engraftment onto nude mice. Similarly, when Smad3 is introduced into SNU-484 human gastric cancer cells (Smad3 deficient), they recover TGF $\beta$ sensitivity, reduced tumorigenicity and enhanced expression of the tumor suppressor E-cadherin [45]. In liver-specific Smad3 transgenic mice, ectopic expression of Smad3 reduces liver susceptibility to chemically induced-hepatocellular carcinoma through the mechanism of promoting hepatocyte apoptosis by repressing $\mathrm{Bcl}-2$ transcription, suggesting a tumor suppressive role for $\mathrm{Smad} 3$ in mouse liver carcinogenesis [50]. Those studies indicated Smad3 has tumor suppressive effects mainly through Smad3-mediated TGF $\beta$ function.

\section{Tumor promotion effects of Smad3}

In three Smad3 knockout mouse models from different laboratories, only one has been reported to develop 
spontaneous colon carcinomas, but later studies suggest the tumor development is related to a helicobacter infection [51-54]. The Smad3+/- and Smad3-/- mice do not develop spontaneous skin tumors. Interestingly, in the two-stage skin carcinogenesis experiment, both Smad3-/- and Smad3+/- mice are resistant to SCC formation, compared to wild-type mice [55]. Smad3 tumors show reduced cell proliferation and inflammation but increased apoptosis [55]. TGF $\beta$ overexpression and subsequent inflammation induced by TPA greatly contribute to cancer development [56]. Therefore, one explanation for the observed resistance to chemically induced skin carcinogenesis in Smad3-/- mice may be attributed to Smad3 deletion-mediated blocking of TGF $\beta$ signaling, evidenced by reduction of TGF $\beta$ induced activator protein-1 family members and TGF $\alpha$ observed in TPA treated Smad3-/- cells and tissue. Similar to our findings, another group also reported Smad3+/- mice develop fewer tumors than the wild-type mice during chemically induced skin carcinogenesis [25]. Thus, in vivo role of Smad3 in skin carcinogenesis is complicated and may be influenced by microenvironment and tissue types. As a major mediator of the TGF $\beta$ signaling pathway, Smad3 may be either a tumor suppressor or promoter in a context dependent manner.

\section{The role of Smad4 in SCC}

\section{Aberrant Smad4 in human cancer}

Smad4 was originally identified as a tumor suppressor in pancreatic cancer [57] and later characterized as a key mediator of TGF $\beta$ signaling [58]. Genetically, homozygous deletion of Smad4 has been identified in pancreatic cancer and colorectal adenocarcinomas [57,59]; germline mutation of Smad4 causes Juvenile Polyposis Syndrome (JPS) [60]. In addition, intragenic mutation and loss of heterozygosity ( $\mathrm{LOH}$ ) at the Smad4 locus has been reported in many tumors, although these genetic alterations may not directly cause inactivation of Smad4 in some cancers [61-63]. Recent genome wide analysis of HNSCC show frequent deletion of the $18 \mathrm{q}$ region where Smad4 is located [43], and heterozygous loss of Smad4 is presented in HNSCC [64]. At the protein and transcriptional level, Smad4 loss and reduction has been found in SCCs from different tissues. In human esophageal SCC, $51.2 \% \sim 67.8 \%$ patients showed Smad4 loss or reduction and Smad4 loss is associated with invasion of esophageal SCC [65,66]. 61.12\% oral squamous cell carcinoma (OSCC) exhibited Smad4 loss [67]. We examined Smad4 mRNA expression in human HNSCC, and found $86 \%$ of tumors and $67 \%$ of adjacent non-malignant mucosa had $>50 \%$ Smad4 reduction. Smad4 protein staining is consistent with mRNA level. In contrast to the strong Smad4 staining in normal mucosa, Smad4 is reduced or lost in HNSCC and adjacent non-tumor tissues. These findings suggest that Smad4 down regulation is an early event in HNSCC development [63]. In addition, we found $\mathrm{LOH}$ at the Smad4 locus in 33\% of HNSCCs, indicating genetic defects and other factors, such as epigenetic, posttranscriptional or posttranslational modifications, cooperatively contribute to reduced Smad4 expression in HNSCC [63]

\section{Smad4 loss in epithelial cells causes spontaneous tumor development in mice}

Germline Smad4 knockout mice died in embryos $[68,69]$. In order to study the role of Smad4 in cancer, mouse models with Smad4 deletion specifically targeted to certain tissue types have been used $[63,70,71]$. These mice had a normal lifespan. MMTV-Cre mediated Smad4 deletion results in spontaneous mammary gland tumors and skin SCC [71]. Smad4 loss related tumorigenesis is frequently accompanied by inactivation of phosphatase and tensin homolog deleted on chromosome 10 (PTEN), activation of AKT, fast proliferation and nuclear accumulation of cyclin D1 and decreased P21 [71]. Keratinocyte-specific Smad4 deletion mediated by K5.Cre further confirmed Smad4 loss interrupted the development of hair follicles and caused spontaneous skin SCC [70]. Smad4/PTEN double knockout mice had accelerated skin tumor formation in comparison with MMTV-Cre or K5-Cre driven Smad4 deletion mice $[70,71]$. When Smad4 and PTEN genes were simultaneously deleted in epithelial cells of the upper digestive tract in Smad4/PTEN double knockout mice, mice rapidly developed forestomach tumors and were moribund within 3 months due to difficulties with food ingestion. The studies suggest Smad4 and PTEN act synergistically to regulate epidermal proliferation and differentiation [70,72]. To understand the role of Smad4 loss in head and neck carcinogenesis, we selectively induced Smad4 deletion in oral epithelia. Similar to spontaneous tumor formation in Smad4-deleted skin and mammary glands $[70,71,73]$, Smad4 loss in head and neck tissues (HN-Smad4-/-) also developed spontaneous HNSCC [63]. Although mice with heterozygous Smad4 deletion (HN-Smad4+/-) do not develop spontaneous HNSCC, they rapidly develop HNSCC (within 3 months) in the presence of a Kras ${ }^{12 \mathrm{D}}$ mutation [63]. This indicates that haploid insufficiency of Smad4, conferring a $50 \%$ of Smad4 protein reduction $[68,69]$, could be sufficient to promote tumor formation. Interestingly, Samd4 loss in head and neck epithelia caused down regulation of Fanc/Brca pathway genes. This finding is intriguing because mutations of Fanc/Brca genes in Fanconi Anemia patients predispose these patients to HNSCC [74]. Different from K5.Smad2-/- mice, Smad4 deletion caused increased TGF $\beta$ expression and associated inflammation and angiogenesis [63,75]. In Smad4 
deleted cells, phospho-Smad3, Smad1 and Smad5 are all increased and Smad3 deletion abrogates Smad4 lossassociated inflammation. Thus, inflammation in Smad4 deleted SCCs appears to be due to Smad3-dependent TGF $\beta$ signaling [63]. Similarly, angiogenesis in Smad4 deleted SCCs is also associated with increased TGF $\beta 1$, which induces angiogenesis directly through activation of Smad1/5 in endothelial cells and through activation of VEGF [75]. Consistent with the finding that Smad4 is required for TGF $\beta$-mediated EMT, Smad4-/- SCCs do not undergo EMT at early stage [14], yet they are able to metastasize [63]. A similar finding was also reported in Smad4 deletion-associated pancreatic cancer [76]. Thus, Smad4 loss-induced metastasis appears to be independent of EMT.

\section{Conclusion}

TGF $\beta$ signaling Smads play different roles in the regulation of tumor development and promotion. Gene deletion and mutation of Smad4 and Smad2 have been identified in certain human cancers and implicated in cancer development. Carcinogenesis studies based on a genetically engineered mouse model with deletion of signaling Smads in epithelia provide fundamental information for the role of individual Smads in SCC initiation and promotion. The roles and mechanisms of signaling Smads in SCC found in our studies are summarized in Figure 2. Genetic deletion of Smad4 in epithelia of a mouse model resulted in spontaneous skin SCC and HNSCC development. Further analysis demonstrated Smad4 loss is associated with inactivation of PTEN and p21, down regulation of Fanc/Brca pathway genes and upregulation of TGF $\beta$ expression. Reduced Fanc/Brca pathway genes directly caused DNA damage which is associated with tumor initiation. Inactivation of PTEN and p21 promote cell proliferation and inhibit cell apoptosis, and cooperate with TGF $\beta$ induced inflammation to accelerate tumor development and progression. Smad2 deletion in epidermal keratinocytes does not initiate tumorigenesis, but accelerates skin tumor development and malignant cancer transition. Smad2 loss transcriptionally upregulates snail and HGF through recruiting Smad3 and Smad4 binding to the SBE site of snail and HGF. Overexpression of Snail

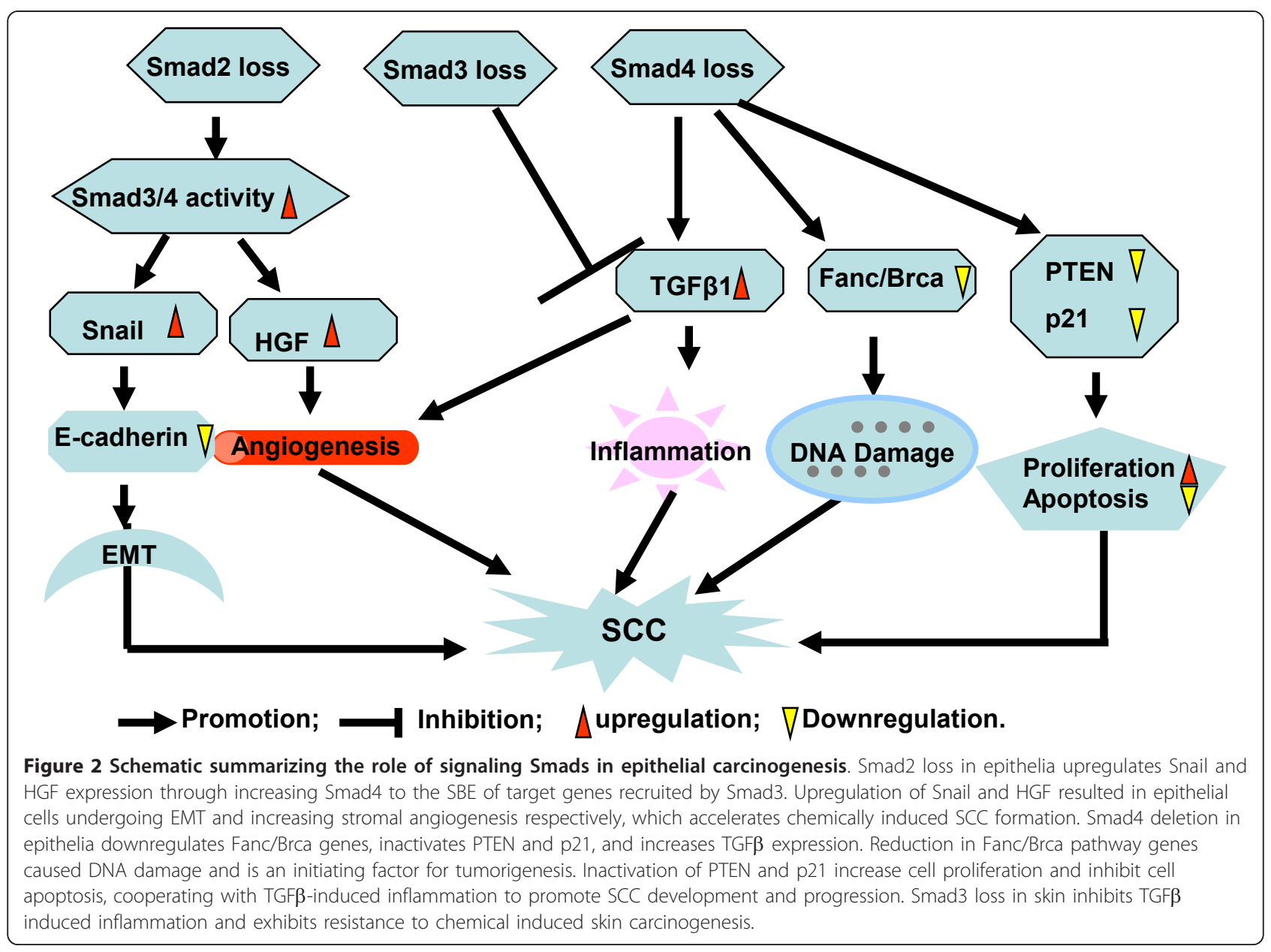


and HGF caused EMT and angiogenesis which is mainly attributed to Smad2 deletion-induced tumorigenesis. Smad3 gene mutation is infrequent in human carcinoma. However, both repressive and promotive role in carcinogenesis have been documented for Smad3, thus Smad3 might play a dual role in tumor development dependent on the context of tumor type and its effect on tumor microenvironment. For instance, keratinocytedeficient Smad3 showed promotion effect on tumor formation and malignant transition under an immune compromised condition mainly due to the loss of TGF $\beta$ mediated cell growth and apoptosis inhibition, but TGF $\beta$-induced inflammation plays a critical role in chemical induced skin carcinogenesis. As individual Smads actively interact, it remains to be determined how loss of more than one Smad gene affects SCC carcinogenesis.

\section{List of Abbreviations}

TGFB: transformation growth factor $\beta$; SCC: squamous cell carcinoma; HNSCC: head and neck squamous cell carcinoma; EMT: epithelialmesenchymal transition; LOH: loss of heterozygosity; HGF: hepatocyte growth factor; PTEN: phosphatase and tensin homolog deleted on chromosome 10; SBE: Smad binding element; TPA: 12-Otetradecanoylphorbol-13-acetate.

\section{Acknowledgements}

The original work from Wang lab was supported by NIH grants CA79998, CA87849, DE15953 and DE20649. G. Han was supported in part by the Cancer League of Colorado. We thank Ms. Pamela Garl for proof reading this review.

\section{Authors' contributions}

GH and XJW co-wrote this review. All authors read and approved the final manuscript.

\section{Competing interests}

The authors declare that they have no competing interests.

Received: 24 October 2011 Accepted: 28 December 2011 Published: 28 December 2011

\section{References}

1. Feng $X H$, Derynck R: Specificity and versatility in tgf-beta signaling through Smads. Annu Rev Cell Dev Biol 2005, 21:659-693.

2. Liu T, Feng $\mathrm{XH}$ : Regulation of TGF-beta signalling by protein phosphatases. The Biochemical journal 2010, 430(2):191-198.

3. Li AG, Lu SL, Han G, Kulesz-Martin M, Wang XJ: Current view of the role of transforming growth factor beta 1 in skin carcinogenesis. J Investig Dermatol Symp Proc 2005, 10(2):110-117.

4. Padua D, Massague J: Roles of TGFbeta in metastasis. Cell research 2009 19(1):89-102.

5. Harradine KA, Akhurst RJ: Mutations of TGFbeta signaling molecules in human disease. Annals of medicine 2006, 38(6):403-414.

6. Slattery ML, Herrick JS, Lundgreen A, Wolff RK: Genetic variation in the TGF-beta signaling pathway and colon and rectal cancer risk. Cancer epidemiology, biomarkers \& prevention: a publication of the American Association for Cancer Research, cosponsored by the American Society of Preventive Oncology 2011, 20(1):57-69.

7. Eppert K, Scherer SW, Ozcelik H, Pirone R, Hoodless P, Kim H, Tsui LC, Bapat B, Gallinger S, Andrulis IL, et al: MADR2 maps to 18q21 and encodes a TGFbeta-regulated MAD-related protein that is functionally mutated in colorectal carcinoma. Cell 1996, 86(4):543-552.
8. Uchida K, Nagatake M, Osada H, Yatabe Y, Kondo M, Mitsudomi T, Masuda A, Takahashi T: Somatic in vivo alterations of the JV18-1 gene at $18 q 21$ in human lung cancers. Cancer Res 1996, 56(24):5583-5585.

9. Yakicier MC, Irmak MB, Romano A, Kew M, Ozturk M: Smad2 and Smad4 gene mutations in hepatocellular carcinoma. Oncogene 1999, 18(34):4879-4883.

10. Papadimitrakopoulou VA, Oh Y, El-Naggar A, Izzo J, Clayman G, Mao L: Presence of multiple incontiguous deleted regions at the long arm of chromosome 18 in head and neck cancer. Clinical cancer research: an official journal of the American Association for Cancer Research 1998, 4(3):539-544

11. Snijders AM, Schmidt BL, Fridlyand J, Dekker N, Pinkel D, Jordan RC, Albertson DG: Rare amplicons implicate frequent deregulation of cell fate specification pathways in oral squamous cell carcinoma. Oncogene 2005, 24(26):4232-4242

12. Takebayashi S, Ogawa T, Jung KY, Muallem A, Mineta H, Fisher SG, Grenman R, Carey TE: Identification of new minimally lost regions on $18 \mathrm{q}$ in head and neck squamous cell carcinoma. Cancer research 2000, 60(13):3397-3403.

13. Qiu W, Schonleben F, Li X, Su GH: Disruption of transforming growth factor beta-Smad signaling pathway in head and neck squamous cell carcinoma as evidenced by mutations of SMAD2 and SMAD4. Cancer letters 2007, 245(1-2):163-170

14. Hoot KE, Lighthall J, Han G, Lu SL, Li A, Ju W, Kulesz-Martin M, Bottinger E, Wang XJ: Keratinocyte-specific Smad2 ablation results in increased epithelial-mesenchymal transition during skin cancer formation and progression. The Journal of clinical investigation 2008, 118(8):2722-2732.

15. Guasch G, Schober M, Pasolli HA, Conn EB, Polak L, Fuchs E: Loss of TGFbeta signaling destabilizes homeostasis and promotes squamous cell carcinomas in stratified epithelia. Cancer Cell 2007, 12(4):313-327.

16. Maliekal TT, Antony ML, Nair A, Paulmurugan R, Karunagaran D: Loss of expression, and mutations of Smad 2 and Smad 4 in human cervical cancer. Oncogene 2003, 22(31):4889-4897.

17. Muro-Cacho CA, Rosario-Ortiz K, Livingston S, Munoz-Antonia T: Defective transforming growth factor beta signaling pathway in head and neck squamous cell carcinoma as evidenced by the lack of expression of activated Smad2. Clin Cancer Res 2001, 7(6):1618-1626.

18. Xie W, Bharathy S, Kim D, Haffty BG, Rimm DL, Reiss M: Frequent alterations of Smad signaling in human head and neck squamous cell carcinomas: a tissue microarray analysis. Oncology research 2003 14(2):61-73.

19. Waldrip WR, Bikoff EK, Hoodless PA, Wrana JL, Robertson EJ: Smad2 signaling in extraembryonic tissues determines anterior-posterior polarity of the early mouse embryo. Cell 1998, 92(6):797-808.

20. Weinstein M, Yang X, Li C, Xu X, Gotay J, Deng CX: Failure of egg cylinder elongation and mesoderm induction in mouse embryos lacking the tumor suppressor smad2. Proceedings of the National Academy of Sciences of the United States of America 1998, 95(16):9378-9383.

21. Heyer J, Escalante-Alcalde D, Lia M, Boettinger E, Edelmann W, Stewart CL, Kucherlapati R: Postgastrulation Smad2-deficient embryos show defects in embryo turning and anterior morphogenesis. Proceedings of the National Academy of Sciences of the United States of America 1999, 96(22):12595-12600.

22. Nomura M, Li E: Smad2 role in mesoderm formation, left-right patterning and craniofacial development. Nature 1998, 393(6687):786-790.

23. Ju W, Ogawa A, Heyer J, Nierhof D, Yu L, Kucherlapati R, Shafritz DA Bottinger EP: Deletion of Smad2 in mouse liver reveals novel functions in hepatocyte growth and differentiation. Molecular and cellular biology 2006, 26(2):654-667.

24. Hamamoto T, Beppu H, Okada H, Kawabata M, Kitamura T, Miyazono K, Kato M: Compound disruption of smad2 accelerates malignant progression of intestinal tumors in apc knockout mice. Cancer research 2002, 62(20):5955-5961.

25. Tannehill-Gregg SH, Kusewitt DF, Rosol TJ, Weinstein M: The roles of Smad2 and Smad3 in the development of chemically induced skin tumors in mice. Vet Pathol 2004, 41(3):278-282.

26. Xu J, Lamouille S, Derynck R: TGF-beta-induced epithelial to mesenchymal transition. Cell Res 2009, 19(2):156-172.

27. Ikushima H, Miyazono K: TGFbeta signalling: a complex web in cancer progression. Nature reviews Cancer 2010, 10(6):415-424 
28. Lebrin F, Deckers M, Bertolino P, Ten Dijke P: TGF-beta receptor function in the endothelium. Cardiovascular research 2005, 65(3):599-608.

29. Tian M, Neil JR, Schiemann WP: Transforming growth factor-beta and the hallmarks of cancer. Cellular signalling 2011, 23(6):951-962.

30. Hoot KE, Oka M, Han G, Bottinger E, Zhang Q, Wang XJ: HGF upregulation contributes to angiogenesis in mice with keratinocyte-specific Smad2 deletion. J Clin Invest 2010, 120(10):3606-3616.

31. Huber MA, Kraut N, Beug H: Molecular requirements for epithelialmesenchymal transition during tumor progression. Current opinion in cell biology 2005, 17(5):548-558.

32. Massague J, Gomis RR: The logic of TGFbeta signaling. FEBS Lett 2006, 580(12):2811-2820

33. Piek E, Moustakas A, Kurisaki A, Heldin CH, ten Dijke P: TGF-(beta) type I receptor/ALK-5 and Smad proteins mediate epithelial to mesenchymal transdifferentiation in NMUMG breast epithelial cells. Journal of cell science 1999, 112(Pt 24):4557-4568.

34. Valcourt U, Kowanetz M, Niimi H, Heldin CH, Moustakas A: TGF-beta and the Smad signaling pathway support transcriptomic reprogramming during epithelial-mesenchymal cell transition. Molecular biology of the cell 2005, 16(4):1987-2002.

35. Benvenuti S, Comoglio PM: The MET receptor tyrosine kinase in invasion and metastasis. Journal of cellular physiology 2007, 213(2):316-325

36. Bussolino F, Di Renzo MF, Ziche M, Bocchietto E, Olivero M, Naldini L, Gaudino G, Tamagnone L, Coffer A, Comoglio PM: Hepatocyte growth factor is a potent angiogenic factor which stimulates endothelial cell motility and growth. The Journal of cell biology 1992, 119(3):629-641.

37. van de Laar IM, Oldenburg RA, Pals G, Roos-Hesselink JW, de Graaf BM, Verhagen JM, Hoedemaekers YM, Willemsen R, Severijnen LA, Venselaar $H$, et al: Mutations in SMAD3 cause a syndromic form of aortic aneurysms and dissections with early-onset osteoarthritis. Nature genetics 2011, 43(2):121-126

38. Regalado ES, Guo DC, Villamizar C, Avidan N, Gilchrist D, McGillivray B, Clarke L, Bernier F, Santos-Cortez RL, Leal SM, et al: Exome Sequencing Identifies SMAD3 Mutations as a Cause of Familial Thoracic Aortic Aneurysm and Dissection With Intracranial and Other Arterial Aneurysms. Circulation research 2011, 109(6):680-686.

39. Ku JL, Park SH, Yoon KA, Shin YK, Kim KH, Choi JS, Kang HC, Kim IJ, Han IO, Park JG: Genetic alterations of the TGF-beta signaling pathway in colorectal cancer cell lines: a novel mutation in Smad3 associated with the inactivation of TGF-beta-induced transcriptional activation. Cancer letters 2007, 247(2):283-292.

40. Sjoblom T, Jones S, Wood LD, Parsons DW, Lin J, Barber TD, Mandelker D, Leary RJ, Ptak J, Silliman N, et al: The consensus coding sequences of human breast and colorectal cancers. Science 2006, 314(5797):268-274.

41. Tram E, Ibrahim-Zada I, Briollais L, Knight JA, Andrulis IL, Ozcelik H: Identification of germline alterations of the mad homology 2 domain of SMAD3 and SMAD4 from the Ontario site of the breast cancer family registry (CFR). Breast cancer research: BCR 2011, 13(4):R77.

42. Riggins GJ, Kinzler KW, Vogelstein B, Thiagalingam S: Frequency of Smad gene mutations in human cancers. Cancer research 1997, 57(13):2578-2580.

43. Agrawal N, Frederick MJ, Pickering CR, Bettegowda C, Chang K, Li RJ, Fakhry C, Xie TX, Zhang J, Wang J, et al: Exome sequencing of head and neck squamous cell carcinoma reveals inactivating mutations in NOTCH1. Science 2011, 333(6046):1154-1157.

44. Mhawech-Fauceglia P, Kesterson J, Wang D, Akers S, Dupont NC, Clark K, Lele S, Liu S: Expression and clinical significance of the transforming growth factor-beta signalling pathway in endometrial cancer. Histopathology 2011, 59(1):63-72.

45. Han SU, Kim HT, Seong DH, Kim YS, Park YS, Bang YJ, Yang HK, Kim SJ: Loss of the Smad3 expression increases susceptibility to tumorigenicity in human gastric cancer. Oncogene 2004, 23(7):1333-1341.

46. Wolfraim LA, Fernandez TM, Mamura M, Fuller WL, Kumar R, Cole DE, Byfield S, Felici A, Flanders KC, Walz TM, et al: Loss of Smad3 in acute Tcell lymphoblastic leukemia. The New England journal of medicine 2004, 351(6):552-559.

47. Millet C, Zhang YE: Roles of Smad3 in TGF-beta signaling during carcinogenesis. Critical reviews in eukaryotic gene expression 2007, 17(4):281-293.
48. Bae DS, Blazanin N, Licata M, Lee J, Glick AB: Tumor suppressor and oncogene actions of TGFbeta1 occur early in skin carcinogenesis and are mediated by Smad3. Molecular carcinogenesis 2009, 48(5):441-453.

49. Vijayachandra K, Lee J, Glick AB: Smad3 regulates senescence and malignant conversion in a mouse multistage skin carcinogenesis model. Cancer research 2003, 63(13):3447-3452.

50. Yang YA, Zhang GM, Feigenbaum L, Zhang YE: Smad3 reduces susceptibility to hepatocarcinoma by sensitizing hepatocytes to apoptosis through downregulation of BCl-2. Cancer cell 2006, 9(6):445-457.

51. Zhu Y, Richardson JA, Parada LF, Graff JM: Smad3 mutant mice develop metastatic colorectal cancer. Cell 1998, 94(6):703-714.

52. Datto MB, Frederick JP, Pan L, Borton AJ, Zhuang Y, Wang XF: Targeted disruption of Smad3 reveals an essential role in transforming growth factor beta-mediated signal transduction. Molecular and cellular biology 1999, 19(4):2495-2504.

53. Yang X, Letterio JJ, Lechleider RJ, Chen L, Hayman R, Gu H, Roberts AB, Deng C: Targeted disruption of SMAD3 results in impaired mucosal immunity and diminished T cell responsiveness to TGF-beta. The EMBO journal 1999, 18(5):1280-1291.

54. Maggio-Price L, Treuting P, Zeng W, Tsang M, Bielefeldt-Ohmann $\mathrm{H}$, Iritani BM: Helicobacter infection is required for inflammation and colon cancer in SMAD3-deficient mice. Cancer research 2006, 66(2):828-838.

55. Li AG, Lu SL, Zhang MX, Deng C, Wang XJ: Smad3 knockout mice exhibit a resistance to skin chemical carcinogenesis. Cancer research 2004, 64(21):7836-7845.

56. Patamalai B, Burow DL, Gimenez-Conti I, Zenklusen JC, Conti CJ, KleinSzanto AJ, Fischer SM: Altered expression of transforming growth factorbeta $1 \mathrm{mRNA}$ and protein in mouse skin carcinogenesis. Molecular carcinogenesis 1994, 9(4):220-229.

57. Hahn SA, Schutte M, Hoque AT, Moskaluk CA, da Costa LT, Rozenblum E, Weinstein CL, Fischer A, Yeo CJ, Hruban RH, et al: DPC4, a candidate tumor suppressor gene at human chromosome 18q21.1. Science 1996, 271(5247):350-353.

58. Zhang Y, Feng X, We R, Derynck R: Receptor-associated Mad homologues synergize as effectors of the TGF-beta response. Nature 1996, 383(6596):168-172

59. Thiagalingam S, Lengauer C, Leach FS, Schutte M, Hahn SA, Overhauser J, Willson JK, Markowitz S, Hamilton SR, Kern SE, et al: Evaluation of candidate tumour suppressor genes on chromosome 18 in colorectal cancers. Nature genetics 1996, 13(3):343-346.

60. Howe JR, Roth S, Ringold JC, Summers RW, Jarvinen HJ, Sistonen P, Tomlinson IP, Houlston RS, Bevan S, Mitros FA, et al: Mutations in the SMAD4/DPC4 gene in juvenile polyposis. Science 1998, 280(5366):1086-1088.

61. Miyaki M, Kuroki T: Role of Smad4 (DPC4) inactivation in human cancer. Biochemical and biophysical research communications 2003, 306(4):799-804.

62. Yang G, Yang X: Smad4-mediated TGF-beta signaling in tumorigenesis. International journal of biological sciences 2010, 6(1):1-8.

63. Bornstein S, White R, Malkoski S, Oka M, Han G, Cleaver T, Reh D, Andersen $\mathrm{P}$, Gross N, Olson S, et al: Smad4 loss in mice causes spontaneous head and neck cancer with increased genomic instability and inflammation. The Journal of clinical investigation 2009, 119(11):3408-3419.

64. Kim SK, Fan Y, Papadimitrakopoulou V, Clayman G, Hittelman WN, Hong WK, Lotan R, Mao L: DPC4, a candidate tumor suppressor gene, is altered infrequently in head and neck squamous cell carcinoma. Cancer research 1996, 56(11):2519-2521.

65. Fukuchi M, Masuda N, Miyazaki T, Nakajima M, Osawa H, Kato H, Kuwano H: Decreased Smad4 expression in the transforming growth factor-beta signaling pathway during progression of esophageal squamous cell carcinoma. Cancer 2002, 95(4):737-743.

66. Natsugoe $\mathrm{S}$, Xiangming $\mathrm{C}$, Matsumoto M, Okumura H, Nakashima S, Sakita H, Ishigami S, Baba M, Takao S, Aikou T: Smad4 and transforming growth factor beta1 expression in patients with squamous cell carcinoma of the esophagus. Clinical cancer research: an official journal of the American Association for Cancer Research 2002, 8(6):1838-1842.

67. Wang X, Sun W, Bai J, Ma L, Yu Y, Geng J, Qi J, Shi Z, Fu S: Growth inhibition induced by transforming growth factor-beta1 in human oral squamous cell carcinoma. Molecular biology reports 2009, 36(5):861-869. 
68. Sirard C, de la Pompa JL, Elia A, Itie A, Mirtsos C, Cheung A, Hahn S, Wakeham A, Schwartz L, Kern SE, et al: The tumor suppressor gene Smad4/Dpc4 is required for gastrulation and later for anterior development of the mouse embryo. Genes Dev 1998, 12(1):107-119.

69. Yang $X, L i C, X u X$, Deng C: The tumor suppressor SMAD4/DPC4 is essential for epiblast proliferation and mesoderm induction in mice. Proc Natl Acad Sci USA 1998, 95(7):3667-3672.

70. Yang L, Mao C, Teng Y, Li W, Zhang J, Cheng X, Li X, Han X, Xia Z, Deng H, et al: Targeted disruption of Smad4 in mouse epidermis results in failure of hair follicle cycling and formation of skin tumors. Cancer research 2005, 65(19):8671-8678.

71. Qiao W, Li AG, Owens P, Xu X, Wang XJ, Deng CX: Hair follicle defects and squamous cell carcinoma formation in Smad4 conditional knockout mouse skin. Oncogene 2006, 25(2):207-217.

72. Teng Y, Sun AN, Pan XC, Yang G, Yang LL, Wang MR, Yang X: Synergistic function of Smad4 and PTEN in suppressing forestomach squamous cell carcinoma in the mouse. Cancer research 2006, 66(14):6972-6981.

73. Li W, Qiao W, Chen L, Xu X, Yang X, Li D, Li C, Brodie SG, Meguid MM, Hennighausen $L$, et al: Squamous cell carcinoma and mammary abscess formation through squamous metaplasia in Smad4/Dpc4 conditional knockout mice. Development 2003, 130(24):6143-6153.

74. Kutler DI, Auerbach AD, Satagopan J, Giampietro PF, Batish SD, Huvos AG, Goberdhan A, Shah JP, Singh B: High incidence of head and neck squamous cell carcinoma in patients with Fanconi anemia. Archives of otolaryngology-head \& neck surgery 2003, 129(1):106-112.

75. Owens P, Engelking E, Han G, Haeger SM, Wang XJ: Epidermal Smad4 deletion results in aberrant wound healing. AmJPathol 2010, 176(1):122-133.

76. Bardeesy N, Cheng KH, Berger JH, Chu GC, Pahler J, Olson P, Hezel AF, Horner J, Lauwers GY, Hanahan D, et al: Smad4 is dispensable for norma pancreas development yet critical in progression and tumor biology of pancreas cancer. Genes \& development 2006, 20(22):3130-3146.

doi:10.1186/2045-3701-1-41

Cite this article as: Han and Wang: Roles of TGF $\beta$ signaling Smads in squamous cell carcinoma. Cell \& Bioscience 2011 1:41.

\section{Submit your next manuscript to BioMed Central and take full advantage of:}

- Convenient online submission

- Thorough peer review

- No space constraints or color figure charges

- Immediate publication on acceptance

- Inclusion in PubMed, CAS, Scopus and Google Scholar

- Research which is freely available for redistribution

Submit your manuscript at www.biomedcentral.com/submit

C Biomed Central 